\title{
Optimal Performans Duygu Durumu, Zihinsel Dayanıklılık, Takım Sargınlığı ve Antrenör Sporcu İliş kisinin Yordayıcısı Olarak Mizah Tarzı: Adolesan Sporcular Üzerine Çalışma
}

\author{
Humor Style As Predictors of Flow, Mental Toughness, Team Cohesion, Coach-Athlete \\ Relationship: Study on Adolescent Athletes
}

\author{
${ }^{1}$ Halis Egemen MERDAN \\ ${ }^{2}$ F. Hülya AŞÇI
}

${ }^{1}$ Hacettepe Üniversitesi, Spor Bilimleri ve Teknolojisi Programı

${ }^{2}$ Marmara Üniversitesi, Spor Bilimleri Fakültesi, Beden Eğitimi ve Spor Eğitimi Bölümü

\section{Yazışma Adresi \\ Corresponding Address:}

\section{Halis Egemen MERDAN}

\section{ORCID No: 0000-0002-9654-8665}

Hacettepe Üniversitesi Spor Bilimleri ve Teknolojisi Programı, Doktora

E-posta:

egemenmerdan@hacettepe.edu.tr

Geliş Tarihi (Received): 01.05.2020 Kabul Tarihi (Accepted): 22.02.2021

\section{öz}

Bu çalışmanın amacı, adolesan sporcuların optimal performans duygu durumu, zihinse dayanıklılık, antrenör sporcu ilişki kalitesi ve takım sargınlığı kavramlarının mizah tarzları ile ilişkisinin incelenmesidir. Çalışmaya 2019-2020 sezonunda İstanbul'da futbol, basketbol, voleybol, hentbol ve su topu branşlarında mücadele eden $139 \mathrm{kIz}$

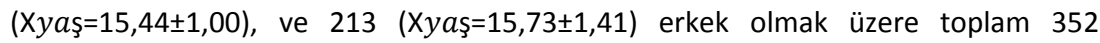
(Xyaş=15,61 $\pm 1,27)$ adolesan sporcu gönüllü olarak katılmıştır. Çalışma kapsamında sporculara "Kişisel Bilgi Formu", "Mizah Tarzları Ölçeği", "Sürekli Optimal Performans Duygu Durum Ölçeği Kısa Formu", "Sporda Zihinsel Dayanıklılık Ölçeği", "Antrenör Sporcu İlişkisi Ölçeği”, "Genç Sporcu Takım Sargınlığı Ölçeği” uygulanmıştır. Verilerin analizinde çoklu hiyerarşik regresyon analizi kullanılmıştır. Yapılan regresyon analizi sonucunda katılımcı mizah tarzının, optimal performans duygu durum, $(\beta=0,12$, $p<0,05)$, zihinsel dayanıklılık $(\beta=0,18, p<0,01)$, antrenör-sporcu ilişki kalitesi ölçeğinin yakınlık $(\beta=0,12, p<0,05)$, bağlıık $(\beta=0,13, p<0,05)$, tamamlayıcılık alt boyutlarının $(\beta=$ $0.12, p<0,05)$ ve takım sargınlığının sosyal sargınlık alt boyutunun $(\beta=0,14, p<0,05)$ pozitif yordayıcısı olduğu bulunmuştur. Ayrıca kendini geliştirici mizah tarzı optimal performans duygu durumun $(\beta=0,23, p<0,01)$ pozitif yordayıcısıdır. Öte yandan, saldırgan mizah tarzının optimal performans duygu durumun $(\beta=-0.12, p<0,05)$, zihinsel dayanıklıı̆ın $(\beta=-0,25, \quad p<0,01)$, antrenör-sporcu ilişkisi kalitesi ölçeğinin yakınlık $(\beta=-0,21, p<0,05)$, tamamlayıcılık alt boyutlarının $(\beta=-0,21, p<0,01)$ ve takım sargınlığının görev sargınlığı alt boyutunun $(\beta=-0,14, p<0,05)$ negatif yordayıcısı olduğu bulunmuştur. Elde edilen bulgular, katılımcı ve saldırgan mizah tarzının, optimal performans duygu durum, zihinsel dayanıkııık, antrenör sporcu ilişki kalitesi ve takım sargınlığı düzeylerinin önemli yordayıcıları olduğunu göstermektedir.

Anahtar Kelimeler: Mizah tarzları, Optimal performans duygu durum, Zihinsel dayanıkııık, Takım sargınlığı, Antrenör sporcu ilişki kalitesi

\section{ABSTRACT}

The aim of this study was to investigate the relationship of humor styles with the flow, mental toughness, coach-athlete relationship quality and team cohesion in adolescent athletes. 139 girls (Mage $=15,44 \pm 1,00$ ) and 213 boys (Mage $=15,73 \pm 1,41$ ), in total 352 (Mage $=15,61 \pm 1,27$ ) adolescent athletes voluntarily participated in this study. "Personal Information Form", "Humor Style Questionnaire", "Short Dispositional Flow Scale-2", "Sport Mental Toughness Questionnaire", "Coach-Athlete Relationship Questionnaire" and "Youth Sport Environment Questionnaire" were administered to athletes. Multiple hierarchical regression analysis was used to analyze. Analysis indicated that affiliative humor style was significant and positive predictor of dispositional flow $(\beta=0,12, p<0,05)$, mental toughness $(\beta=0,18, p<0,01)$, closeness $(\beta=$ $0,12, p<0,05)$, commitment $(\beta=0,13, p<0,05)$, complementarity subscales of coachathlete relationship quality $(\beta=0,12, p<0,05)$, and social cohesion subscale of team cohesion $(\beta=0,14, p<0,05)$ in adolescent athletes. Moreover, self-enhancing humor style was significant and positive predictor of dispositional flow $(\beta=0.23, p<0,01)$. Furthermore, aggressive humor style was significant and negative predictor of dispositional flow $(\beta=-0,12, p<0,05)$, mental toughness $(\beta=-0,25, p<0,01)$, closeness $(\beta=-0,21, p<0,05)$, complementarity subscales of coach-athlete relationship quality $(\beta=$ $-0,21, p<0,01)$ and task cohesion subscale of team cohesion $(\beta=-0,14, p<0,05$. In conclusion, affiliative and aggressive humor styles are the important predictors of dispositional flow, mental toughness, coach - athlete relationship quality and team cohesion levels in adolescent athletes.

Keywords: Humor style, Flow, Mental toughness, Team cohesion, Coach-athlete relationship. 



\section{GíRIŞ}

Pozitif psikoloji, genel psikoloji yaklaşımlarından farklı olarak bireydeki problemlerin tedavisinden ziyade, insanın mutluluğu, pozitif duyguları, yaşam doyumu ve refahı için gerekli olan kavramları araştırır (Teztel, 2016). Bu bağlamda, pozitif psikoloji daha güçlü bir yaşam tarzı ve daha fazla psikolojik iyi oluşa yol açabilecek cesaret, yaratıcılık, merak, öğrenme aşkı ve umut gibi karakter özelliklerini ele almaktadır (Peterson ve Seligman, 2004). Bu özelliklerden biri de mizahtır.

Mizah, pozitif psikoloji için kişilerin zorlu durumlarla başa çıkmalarını ve karşılaştıkları bu zorluklara uyum sağlamalarını kolaylaştıran olumlu özelliklerden biridir (Martin ve diğ., 2003). Mizah tarihsel süreç içerisinde birçok araştırmacı tarafından ele alınmış ve farklı şekillerde tanımlanmışıtır. Freud'a göre mizah, komik durumlarda meydana gelen ve gülme eylemiyle son bulan, çoğunlukla hoş hissettiren ve kişinin zorlu olaylarla karşılaştı̆ıında, bu olayın negatif etkilerinden uzaklaşmasını sağlayan savunma mekanizmalarından biridir (Susa, 2002). Martin ve diğ. (2003)'ne göre ise mizah, gülümsemeyi sağlayan durum ya da gülmek kavramının içerdiği durumlardır. Bunun yanı sıra, mizah olumlu bir kişilik özelliği olarak da alan yazında ele alınmış (Peterson ve Seligman, 2004; Martin, 2007) ve mizah duygusundan yoksun olmanın bencillik, fanatiklik, fazla ciddi olmak gibi olumsuz kişilik özellikleri ile eşleştirildiği belirtmişstir (Martin, 2007). Martin ve diğ. (2003), bireylerin kişilerarası ilişkilerinde veya kendi içinde sahip oldukları mizah duygusunu nasıl kullandıklarını açıklamak için çok boyutlu mizah tarzları kavramını ortaya atmışlardır. Temelde uyumlu ve uyumsuz olmak üzere dört farklı mizah tarzı -kendini geliştirici, saldırgan ve kendini yıkıcı- olduğunu ileri sürülmüştür (Martin ve diğ., 2003).

Katılımcı ve kendini geliştirici mizah tarzı, mizahın uyumlu/olumlu yönleri olarak ele alınırken; saldırgan ve kendini yıkıcı mizah tarzı mizahın uyumsuz-olumsuz yönleri olarak ele alınmaktadır (Yerlikaya, 2007). Katılımcı mizah (diğerine yönelik ve yardımsever), ilişkileri güçlendirmek için tasarlanmış esprili hikayeler ve şakalar söylemekle karakterize edilir. $\mathrm{Bu}$ tarza sahip bireyler, kişilerarası ilişkileri kolaylaştırmak ve gerilimleri azaltmak için başkalarını eğlendirme, şakalar yapma davranışları gösterirler (Martin ve diğ. 2003). Mizah, birey tarafından kendine ve diğerlerine saygılı bir biçimde kişiler arası etkileşimleri geliştirici bir biçimde kullanılır (Yerlikaya, 2009). Olumlu mizah tarzlarından olan kendini geliştirici mizah (kendi kendine yönelen ve yardımsever), bireylerin hem kendi hem de diğerlerinin gereksinimlerini dikkate alarak, stresle başa çıkmada, etkili stratejiler geliştirebilmek için çaba harcamalarını ifade eder (Martin ve diğ., 2003). Kendini geliştirici mizah tarzına sahip bireylerin, yaşama karşı mizahi bakış açısı vardır ve yaşamın uyumsuzlukları, stres ya da sıkıntı karşısında bile komik bir bakış açısı ile yaklaşıp, mizahı duyguların kontrolünde ve stresle başa çıkmada kullanırlar (Yerlikaya, 2009). Öte yandan, saldırgan mizah tarzı uyumsuz/olumsuzdur. Saldırgan mizah tarzına sahip bireyler başkalarına yöneltilen alaycı ve küçük görme hislerine sahiptir (Martin, 2007). Saldırgan mizah tarzı (diğerlerine yönelik ve alçaltıcı) aşağılama, alay etme, küçük görme amaçları ile kullanır (Martin ve diğ., 2003). Kendini yıkıcı mizah tarzı (kendine yönelen ve alçaltan), kendi kişisel eksikliklerini sıklıkla vurgulayan veya diğerlerini kendiyle alay etmeye teşvik eden mizahla karakterizedir ve başkalarından onay almak için kendi zayıflıklarını ön plana çıkarır (Martin ve diğ., 2003). Bu bağlamda, bu tarz kişisel iyi olmayı, kendini kabulü olumsuz etkiler, düşük benlik algısına ve kişilerarası ilişkilerin engellenmesine neden olur (Martin, 2007).

Pozitif psikolojide önemli yer tutan mizah tarzları ile ilgili birçok çalışma yapılmıştır. Alan yazın incelendiğinde mizah tarzlarının stres, depresyon, kaygı, yalnızlık, utangaçlık, psikolojik iyi oluş, benlik saygısı, gibi kişiye ait psikolojik yapılarla ilişkisi ele alınmıştır (Fidanoğlu, 2006; Mauriello ve Mcconatha 2007; Rnic ve diğ., 2016, Hampes 2005; Hampes 2006; Erickson ve Feldstein, 2007; Kuiper ve diğ., 2004; Liu 2012; Falanga ve diğ., 2014; Ford ve diğ., 
2014; Ford ve diğ., 2016; Paez ve diğ., 2014). Kişiye ait psikolojik yapıların yanı sıra, mizahın kişilerarası ilişkilerdeki rolü de (Cann ve diğ., 2009; Hill ve diğ., 2013) farklı örneklemlerde farklı yaşam ortamlarında ele alınmıştır. Mizah tarzları ile farklı psikolojik yapıların ilişkisi ele alındığı yaşam ortamlarından biri de spor ortamı ve sporculardır. Çok fazla çalışma yapılmamakla birlikte, sporcuların sahip oldukları mizah tarzlarının sürekli kaygı (Iş̧ı ve diğ., 2017), memnuniyet (Sullivan, 2013), kişilik (Işık ve Cengiz, 2018), kaygı ve duygu durum (Szabo, 2003), algılanan antrenör davranışı (Grisaffe ve diğ., 2003) gibi yapılarla olan ilişkileri araştırmacılar tarafından incelenen konular olmuştur.

Alan yazında yer alan yukarıda değinilen çalışmalara bakıldığında, spor ortamında mizah tarzlarının daha çok kişiye ait psikolojik yapılarla ilişkisinin ele alındığı̆ çalışmalarda son yıllarda egzersiz ve spor psikoloji alan yazınında popüler olan ve sporda başarı için önem arz eden kişiye ait ve kişilerarası psikolojik yapıların ilişkisininin araştırılmadığı görülmektedir.

Mizah tarzları ile ilişsisi ele alınabilecek kişiye ait yapılardan biri optimal performans duygu durumudur. Optimal performans duygu durumu mizah kavramı gibi pozitif psikolojinin önemli kavramlarından biridir. 1960'lı yıllarda Csikszentmihalyi tarafından kişilerin serbest vakitlerinde uğraştıkları aktivitelere onları çeken şeyin sebeplerini ortaya çıkarmak üzere yapılan çalışmalarda ele alınan optimal performans duygu durumu bir aktiviteyle yoğun biçimde ilgilenmek ve bundan haz duymak olarak adlandırılmıştır (Aş̧̧ı ve diğ., 2007). Csikszentmihalyi (1975), akış deneyiminin çok boyutlu bir yapı olduğunu; bu yapı içerisinde akış deneyiminin oluşmasına öncellik eden ve akış deneyiminin yaşanması sırasında oluşan özellikleri içeren 9 alt boyutun olduğunu belirtmiştir. Optimal performans duygu durum yapısı içerisinde yer alan alt boyutlar, belirli geri bildirim (bireyin davranışı ile ilgili anlık geri bildirim), eylem-farkındalık birleşimi (aktivite ile bütün olma ve farkındalık oluşumu), açık (net) hedefler (hedefin açık bir şekilde belirtilmesi), kontrol duygusu (performansı bütünüyle kontrol altına alma duygusu), amaca ulaşma deneyimi (aktivitenin ödüllendirici ve eğlenceli oluşu), kendilik farkındalığının azalması (öz-bilinç durumunun olmaması), görev zorluğu ve beceri dengesi (algılanan zorluk ile kişinin becerisi arasındaki denge), zamanın dönüşümü (zamanın çok hızlı veya yavaş akması) ve göreve odaklanmadır (göreve bütünüyle odaklanma).

Csikszentmihalyi'nin (1990) optimal performans duygu durumunun oluşumu ile ilgili ortaya attığı modelde; aktivitenin zorluğu fazla, algılanan yeterlilik düşükse kayg1; aktivitenin zorluğu az algılanan yeterlilik azsa sıkılma; aktivitenin zorluğu az algılanan yeterlilik yüksekse sıkılma; aktivitenin yeterliliği ve algılanan yeterlilik dengedeyse optimal performans duygu durumu deneyimlenmektedir. Alan yazında optimal performans duygu durumunun oluşmasına engel olan ve kolaylaştıran bireysel ve durumsal faktörler araştırmacılar tarafından ele alınmıştır. Swann ve diğ. (2012), elit sporcular üzerinde yapılan niteliksel ve niceliksel araştırmalarından yola çıkarak yaptıkları derleme çalışmasında, içsel (odaklanma, uyarılmışlık, motivasyon, özgüven, düşünceler ve duygulanımlar), dışsal (çevresel şartlar, hava, seyirci) ve davranışsal (psikolojik hazırlanma) faktörlerin optimal performans duygu durumunun deneyimlenmesini etkilediğini; uygun odaklanma, fiziksel ve zihinsel hazır olma, özerk güdülenme, uygun canlılık düzeyi, olumlu düşünce, kendine güven, olumlu geribildirim, ve uygun çevre koşullar gibi faktörlerin optimal performans duygu durumunun yaşanma olasılığını arttırdığını, odaklanamama, fiziksel ve zihinsel olarak hazır olmama, özerk olmayan güdüleneme, aşırı uyarılmışlık, olumsuz düşünceler, düşük kendine güven, performans hataları ve uygun olmayan çevresel koşulların ise optimal performans duygu durumun yaşanmasını engellediğini ortaya koymuşlardır. Çok boyutlu bir yapı olarak konumlandırılan, optimal performans duygu durum deneyimi pozitif duygulanım, iyimserlik ve mutlulukla ilişkili olduğu yapılan çalışmalarla ortaya konmuştur (Fullagar ve Kelloway, 2009; Hunter ve Csikszentmihalyi, 2003). Benzer şekilde, çalışmada ele alınan mizah tarzının, sosyal deneyim ve yaşam olaylarından 
alınan zevk, tatmin, iyimserlik ve mutluluk gibi kavramları etkilediği bilinmektedir (Zhao ve diğ., 2014, Dyck ve Holtzman, 2013; Cann ve Etzel, 2008). Bu bağlamda da sporcuların sahip olduğu mizah tarzının, pozitif psikoloji kavramı olan optimal performans duygu deneyimine ulaşma ile ilişkili olabileceği ileri sürülebilir.

Optimal performans duygu durum gibi zihinsel dayanıklılık da pozitif psikolojide önemli yer tutan ve egzersiz ve spor psikolojisi alan yazınında giderek popülerleşen bir diğer kavramdır. Zihinsel dayanıklılık, başarıya ulaşmak, yüksek performans sergileyebilmek ve sürdürebilmek için sporcuların sahip olması gereken özelliklerden biridir (Gucciardi ve diğ., 2009, Cox, 2012). Zihinsel dayanıklılık baskı, stres ve sıkıntı ile başa çıkma becerisi (Goldberg, 1998) ve üstün zihinsel becerilere sahip olmak şeklinde tanımlanmıştır (Jones ve diğ., 2002). Yapılan çalışmalar, zihinsel dayanıklılığı yüksek sporcuların baskı altında daha sakin kalabildiğini (Thelwell ve diğ., 2005), daha çok problem ve yaklaşma yönelimli başa çıkma stratejilerini kullandığını (Nicholls ve diğ., 2008), stres seviyelerinin daha düşük, yılmazlık seviyelerinin ise daha yüksek olduğunu ortaya koymuştur (Cowden ve diğ. 2016). Bu bağlamda, kişinin zorluklar karşısındaki tutumu, stresle başa çıkma becerisi, kaygı ve depresyon seviyeleri üzerinde etkisi olan mizah tarzının (Martin ve diğ. 2003), sporcuların zihinsel dayanıklılık seviyeleri ile ilişkili olabileceği söylenebilir. Alan yazın incelendiğinde de, sınırlı sayıda yapılan çalışmada, olumsuz mizah tarzlarının zihinsel dayanıklılıkla negatif, olumlu mizah tarzlarının ise pozitif ilişkili olduğu bulunmuştur (Yaprak ve diğ. 2018; Veselka ve diğ. 2010).

Optimal performans duygu durumu ve zihinsel dayanıklılık gibi kişiye ait psikolojik yapıların yanı sıra, spor ortamında yapılan çalışmalarda sporda başarı için önem arz eden kişilerarası yapıların da örneğin; takım sargınlığı ve antrenör sporcu ilişkisi kalitesinin mizah tarzları ile ilişkisinin ele alınmadı̆̆ı görülmektedir. Genel psikoloji alan yazınında yapılan çalışmalar olumlu mizah tarzında yüksek puanlara sahip bireylerin, yabancılarla konuşma ve arkadaşlık kurmayı daha iyi başarabilecekleri ortaya konmuştur (Kuiper ve diğ., 2004). Bir başka çalışmada ise olumlu mizah tarzlarının, kişinin kendini açıklama becerisi ile pozitif ilişkili olduğunu, mizahın kendisiyle ilgili kişisel bilgileri başkalarına aktarmanın iyi bir yolu olabileceği öne sürülmüştür (Yip ve Martin 2006). Ayrıca araştırmacılar, saldırgan mizah tarzı kullanma eğiliminde olan kişilerin, başkalarına duygusal destek sağlama ve ilişkilerde çatışmaları yönetme konusunda daha düşük bir yeteneğe sahip olduklarını; saldırgan mizahın altında yatan düşmanca tutumların, bireylerin başkalarına karşı empatik ve destekçi olmalarını zorlaştırabileceğini ve saldırganlık, alaycı tutumların gerginliği azaltmada etkin olmadığını belirtmişlerdir (Kuiper ve diğ., 2004; Yip ve Martin 2006). Tüm bu çalışmalardan yola çıkarak olumlu mizah tarzlarının ilişki kalitesini pozitif, olumsuz mizah tarzlarının negatif etkilediği söylenebilir. Grisaffe ve diğ. (2003) 33 üniversite takımı sporcusuyla yaptıkları araştırmada, antrenörlerin mizah kullanımı ile oyuncuların antrenörden hoşlanma durumunun pozitif ilişkili olduğunu ortaya koymuşlardır. Bu bağlamda, mizah tarzlarının spor ortamında önemli yer tutan antrenör sporcu ilişki kalitesine de etkisi olabileceği öne sürülebilir. Diğer kişilerarası ilişkiler gibi, antrenör sporcu ilişkisi de karşılıklı ve nedensel olarak birbirine bağımlı sosyal bir durumdur. Antrenör ve sporcu arasındaki ilişki, tarafların kişilerarası düşünceleri, duyguları ve davranışları ile şekillenir (Jowett ve Shanmugam, 2016). Son yıllarda antrenör -sporcu arasındaki ilişki kalitesi Jowett ve Ntoumanis (2004) tarafından geliştirilen 3Cs modeli kapsamında yakınlık, bağlılık ve tamamlayıcılık boyutları ile ele alınmaktadır. Bu üç boyut ilişkinin duygusal, bilişsel ve davranışsal unsurlarının içermektedir (Jowett ve Meek, 2000; Jowett ve Cockerill, 2003). Modelde yakınlık, duygularla ilgilidir ve antrenör ve sporcu arasında gelişen, birbirini sevme, karşılıklı güven, saygı ve takdir etme gibi duygusal bağları yansıtır (Davis ve diğ., 2018). İlişkinin bilişsel unsuru olan bağlılık, antrenör ve sporcuların gelecekte ilişkiyi sürdürme isteğini yordar (Jowett ve Cockeriill, 2003, Jowett ve Ntoumanis, 2004). Sporcunun ve / veya antrenörün uzun süre sik1 sıkıya bağlı bir sportif ilişki sürdürme konusundaki “düşünceleri” ile tanımlanır (Davis ve diğ., 2018). Tamamlayıcılık, 
antrenör ile sporcunun performansı yükseltmek için uyumlu, hassas, motive şekilde beraber çalışmalarını açıklar (Jowett ve Timson- Katchis, 2005).

Kişilerarası ilişki kalitesinin yanı sıra genel psikoloji çalışmaları mizahın grup ve çalışma ortamlarındaki takım sargınlı̆̆ını etkilediğini ortaya koymuştur. Takım sargınlğı, grup içindeki bireylerin birbirleriyle olan bağı, ortak hedeflerin gerçekleştirilmesi ve duygusal gerekliliklerin yerine getirilmesi amacıyla bir arada bulunan kişilerden meydana gelen aktif süreçtir (Carron, ve diğ., 1999). Mizah tarzlarının özellikleri düşünüldüğünde bu aktif sürecin bireylerin sahip oldukları mizah tarzlarından etkilenmesi olasıdır. Nitekim gerek spor gerekse genel psikoloji alanında yapılan çalışmalar bunu desteklemektedir. Örneğin, genel psikoloji alanında yapılan çalışmalar, olumlu mizah tarzına sahip çalışanların iş arkadaşlarından daha memnun, iş doyumu ve takıma bağlılıkları yüksek bireyler olduğunu göstermiştir (Romero ve Arendt, 2011; Romero ve Cruthrids, 2006; Romero ve Pescosolido, 2008). Ayrıca mizah kullanımının, refahı ve verimi artırabileceğini, ekip gelişimi ve takım süreçlerini kolaylaştırabileceğini bilinmektedir (Dziegielewski, 2003). Spor alanında yapılan çalışmalar, katılımcı mizah tarzının takım sargınlığı ile pozitif ilişkisi olduğunu göstermiştir ve katılımcı mizah kullanımının takım sargınlığını artırmak için etkili bir yöntem olabileceği öne sürülmüştür (Tremayne, 2010). Buna ek olarak, antrenörlerin mizah kullanmasının takım kimliğine pozitif etkisi olduğunu ve antrenörlerin mizah duygusuna sahip olmasının, mizahı spor ortamında kullanmalarının takım atmosferini olumlu yönde etkilediğini göstermiştir (Ronglan ve Aggerholm 2014; Høigaard ve diğ. 2017).

Alan yazında yer alan yukarıda bahsedilen çalışmalardan yola çıkarak, bu çalışmanın amacı, adolesan sporcularda, optimal performans duygu durumu, zihinsel dayanıklılık, antrenör sporcu ilişki kalitesi ve takım sargınlığı ile mizah tarzları arasındaki ilişkisinin incelenmesidir. Mizah tarzlarının, spor ortamında, kişi içi ve kişilerarası yapıları ne şekilde etkileştiğinin araştırılmasının spor psikolojisi alanında çok fazla çalışılmamasından dolayı alana katkı sağlayacağı düşünülmüştür.

\section{YÖNTEM}

Örneklem: Araştırmanın örneklemi olasılıksız örneklem yöntemlerinden uygun örnekleme yöntemi kullanılarak belirlenmiştir. Bu bağlamda çalışmaya 2019-2020 sezonunda İstanbul ilinde futbol, basketbol, voleybol, hentbol ve su topu branşlarında mücadele eden spor kulüplerinden 139 kı ve 213 erkek olmak üzere toplam 352 sporcu gönüllü olarak katılmıştır. Çalışmaya katılan sporcuların yaş aralı̆̆ı 14-18 ( $\overline{\mathbf{x}}$ yaş $=15,61 \pm 1,27$ yıl) arasında olup kız sporcuların yaş ortalaması $15,44 \pm 1,00$ ve erkek sporcuların yaş ortalaması $15,73 \pm 1,41$ 'dir. Sporcuların spor deneyimi ortalaması

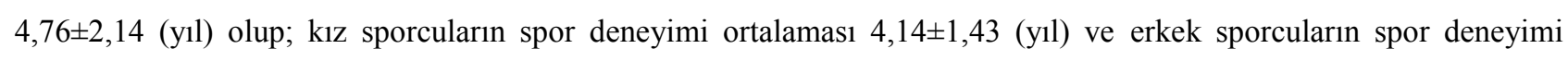

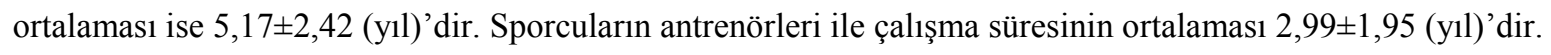

\section{Veri Toplama Araçları:}

Kişisel bilgi formu: Çalı̧̧maya katılan sporcuların yaş, cinsiyet, spor türü, spor deneyimi, millilik durumu, antrenman sıklığı gibi özelliklerini belirlemek amacıyla araştırmacı tarafından hazırlanan Kişisel Bilgi Formu kullanılmıştır.

Mizah tarzları ölçeği: Mizah Tarzları Ölçeğinin 60 maddeden oluşan uzun versiyonunu Martin ve Puhlik-Dorris (1999) dört mizah tarzını ölçmek amacıyla geliştirmişlerdir. Martin ve diğ. (2003) daha sonra ölçeği revize ederek 32 maddelik kısa formunu oluşturmuşlardır. Bu çalışmada 32 maddelik revize edilen kısa form kullanılmıştır. Ölçek, katılımcı mizah, kendini geliştirici mizah, saldırgan mizah ve kendini yıkıcı mizah" tarzı olmak üzere dört alt boyuttan oluşmaktadır. Mizah Tarzları Ölçeği yedili Likert tipinde ve 1 (kesinlikle katılmıyorum) ile 7 (tamamıyla katılıyorum) 
arasında puanlanmaktadır. Ölçeğin adolesanlar için Türkçe geçerlik ve güvenirlik çalışması Yerlikaya (2007) tarafından yapılmıştır. Türkçe uyarlama çalışması sonucunda ölçeğin iç tutarlık Cronbach alfa katsayıları Kendini Geliştirici Mizah ve Katılımcı Mizah için 0,75, Saldırgan Mizah için 0,64, Kendini Yıkıcı Mizah için ise 0,63 olarak bulunmuştur.

Sürekli optimal performans duygu durum ölçeği kısa formu: Katılımcıların optimal performans duygu durumunun ölçümünde "Sürekli Optimal Peformans Duygu Durum Ölçeği Kısa Formu-2" kullanılmıştır. Ölçeğin uzun formu Jackson ve Eklund (2004) tarafindan geliştirilmiştir ve 36 maddeden oluşmaktadır. Çalışmada kullanılan kısa form ise Jackson ve diğ. (2008) tarafindan geliştirilmiştir. Ölçeğin kısa formu dokuz maddeden oluşmaktadır ve beşli Likert ölçek yapısındadır (Jackson ve diğ., 2008). Ölçeğin kısa formu Çağlar ve diğ. (2015) tarafından Türkçe’ye uyarlanmıştır. Ayrıca, ölçeğin Türkçe formunun adolesanlar için geçerlik ve güvenirliği beden eğitimi dersi için test edilmiş ve iç tutarlılık katsayısı 0,77 olarak bulunmuştur (Keskin ve Aş̧̧ı, 2017).

Sporda zihinsel dayanıklılı ölçeği: Sporcuların zihinsel dayanıklıllı̆ını ölçmek için Sporda Zihinsel Dayanıklılık Ölçeği kullanılmıştır. Ölçek, Gucciardi ve diğ. (2016) tarafından geliştirilmiştir ve tek alt boyuttan oluşmaktadır. Yedili Likert tipi (1=Tamamen Yanlış $-7=$ Tamamen Doğru) olan ölçekte toplam sekiz madde bulunmaktadır. Ölçeğin geçerlik ve güvenirliği 400 adolesan sporcu üzerinde Özgör ve Aşçı (2018) tarafindan yapılmıştır ve cronbach alfa iç tutarlılık katsayısı 0,78 olarak hesaplanmıştır.

Antrenör sporcu ilişsisi ölçeği: Sporcuların antrenörleri ile olan ilişki kalitesini belirlemek için Antrenör Sporcu İlişkisi Ölçeği kullanılmıştır. Jowett ve Ntoumanis (2004) tarafından geliştirilen ölçek, antrenör sporcu ilişkisini değerlendirmek amacıyla "yakınlık (duygusal), bağlılık (bilişsel) ve tamamlayıcılık (davranışsal)" alt boyutlardan ve 11 maddeden oluşmaktadır. Ölçekte yer alan maddeler 7'li likert tipi-1 kesinlikle katılmıyorum, 7 kesinlikle katılıyorumdeğerlendirme ölçeği kullanılarak cevaplandırılmaktadır. “Antrenör-Sporcu İlişkisi Envanteri'nin (Coach-Athlete Relationship Questionnaire, CART-Q) Türkçe geçerlik ve güvenirliği Altıntaş ve diğg. (2012) tarafindan yaş ortalaması 15,6 olan 151 adolesan sporcu üzerinde yapılmıştır. Antrenör sporcu ilişkisi ölçeğinin sporcu formu için iç tutarlık değerleri 0,82 ile 0,90 arasında bulunmuştur (Altıntaş ve diğ., 2012).

Genç sporcu takım sargınlı̆̆ı ölçeğgi: Ölçek Eys ve diğg. (2009), tarafindan genç sporcuların takım sargınlığı düzeylerini değerlendirme amacıyla geliştirilmiş̧ir. Görev sargınlığı ve sosyal sargınlık olarak iki alt boyuttan oluşmaktadır. 18 maddeden oluşan ve 9'lu Likert tipi bir ölçektir (Eys ve diğ., 2009). Ölçeğin Türkçe geçerlik güvenirlik çalışması Sezer ve Kocaeski (2018) tarafından yapılmıştır ve iç tutarlılık katsayıları görev sargınlığ için 0,87, sosyal sargınlık için 0,87 ve genel olarak 0,89 bulunmuştur.

Verilerin Toplanması: Ölçeklerin kullanımı için ölçek sahiplerinden gerekli izinler alınmıştır. Ölçekler, sporcu ve sporcu ailelerine gerekli bilgilendirme yapılıp, onayları alınarak,-sporcuların dinlenme saatlerinde, antrenman sahalarında yüz yüze uygulanmıştır. Araştırmaya 2019-2020 sezonunda İstanbul ilinde mücadele eden sporcular katılmışıtır. Etik kurul onayı, araştırmanın gerçekleştirilmesi amacı ile Marmara Üniversitesi Sağlık Bilimleri Enstitüsünden (18.03.201980) alınmıştır.

Verilerin Analizi: Analizlere geçilmeden önce veri setinde hatalı veri girişi olup olmadığını görmek için kayıp ve boş veriler incelenmiştir. Veri setinde herhangi kayıp ya da boş verinin olmadığı bulunmuştur. Mahalanobis uzaklık değerleri yardımı ile veri setindeki uç değerler ve çok değişkenli normallik varsayımının karşılanıp karşılanmadığı değerlendirilmiş ve 11 uç değer veri setinden çıkarılmıştır. Basıklık ve çarpıklık katsayıları incelendiğinde, değişkenlere ait çarpıklık katsayısı -0,22 ile 2,40 aralığında, basıklık katsayısı -0,16 ile 6,98 aralığındadır. Basıklık ve çarpıklık katsayılarının ideal olarak +1 ve -1 arasında olmasının arzulandığı, ancak +2 ve -2 arasındaki değerlerin de kabul 
edilebilir olduğu belirtilmektedir (George ve Mallery, 2016). Bu bağlamda sadece antrenör sporcu ilişki kalitesi yakınlık alt boyut puanı normal dağılım için gereken varsayımı karşılamamaktadır.

Ön analizlerin ardından, mizah tarzlarının çalışmada ele alınan değişkenleri yordayıp yordamadığını belirlemek için hiyerarşik regresyon analizi kullanılmıştır. Yapılan çoklu hiyerarşik regresyon analizinde bağımsız değişken olarak mizah tarzlarının alt boyutları (katılımcı, kendini geliştirici, saldırgan ve kendini yıkıcı), bağımlı değişkenler olarak ise zihinsel dayanıklılık, optimal performans duygu durum, antrenör sporcu ilişki kalitesi ve takım sargınlığı alt boyutları ele alınmıştır. Regresyon analizi varsayımları çerçevesinde, değişkenler arasında çoklu bağlantılılık, otokorelasyon probleminin normallik, doğrusallık ve hata varyanslarının eşit dağılımı incelenmiştir (Field, 2009; Tabachnick ve Fidell, 2013). Bağımlı değişkenin doğrusal olup olmadığı saçılım grafikleri aracılığı ile incelenmiş ve doğrusallık varsayımının karşılandığı görülmüştür. Pearson ilişki katsayısı ile çoklu bağlantılılık varsayımı için değişkenler arasındaki ilişki ele alınmış ve elde edilen değerlerin çoklu bağlantılılık göstergesi olan 0,80 seviyesinden düşük olduğu gözlenmiştir (Field, 2009). Regresyon analizi kapsamında çoklu bağlantılılık durumu varyans enflasyon faktörü (VIF) ve Tolerans (TOL) değerlerine bakılarak da incelenmiştir. TOL değerinin 0,10'un altında, VIF değerinin ise 10'un üzerinde olması bağımsız değişkenler arasında yüksek ilişki olduğunu belirtmektedir (Dormann ve diğ., 2013). Çalışma kapsamında TOL değeri 0,97- 0,73 aralığında, VIF değeri ise $1,03-1,36$ aralığında tespit edilmiştir. Elde edilen bu değerler tahmin değerleri arasında istatistiksel olarak anlamlı bir ilişki olmadığını belirtmektedir.

Varsayımların test edilmesinden sonra veri setinin regresyon analizi için uygun olduğuna karar verilmiştir. Bu bağlamda hiyerarşik regresyon analizinde, her bir bağımlı değişken için, (optimal performans duygu durumu, zihinsel dayanıklılık, antrenör-sporcu ilişkisi, takım sargınlığı) bağımsız değişkenler olan cinsiyet ve spor deneyimi kontrol değişkeni olarak modelin birinci adımında, mizah tarzlarının alt boyutları ise ikinci adımda modele dahil edilmiştir. Cinsiyet ve spor deneyimi kategorik değişken oldukları için analizlere alınmadan önce yapay (dummy) bir değişken olarak cinsiyet; 0 (kız) ve 1 (erkek) ve spor deneyimi; 0 (1-4 yıl) ve 1 (5 yıl ve üstü) şeklinde kodlanmıştır. Bu değişkenler yapılan bağımsız örneklerde t-test sonuçlarına göre kontrol değişkeni olarak modele eklenmiştir. Yapılan bağımsız örneklerde t-test analiz sonuçları cinsiyete göre adolesan kız ve erkek sporcuların katılımcı, saldırgan ve kendini yıkıcı mizah tarz puanlarında, antrenör sporcu ilişki kalitesinin yakınlık ve tamamlayıcılık alt boyutunda zihinsel dayanıklılıkta ve görev sargınlığı puanlarında fark bulunmuş̧ur. Spor deneyimine göre ise mizah tarzlarından saldırgan mizah alt boyutunda anlamlı fark olduğu bulunmuştur. Bağımsız örneklerde t-test çalışmanın kontrol değişkenlerinin desteklenmesi amacı ile yapıldığı için bulgular kısmında bu analizlere yer verilmemiştir.

Analizler SPSS 22 paket programında yapılmış olup anlamlılık düzeyi 0.05 kabul edilmiş̧ir.

\section{BULGULAR}

Çalışmada ele alınan bağımlı ve bağımsız değişkenlere ilişkin tüm örneklem grubuna ait tanımlayıcı istatistikler Tablo 1'de verilmiştir. Değişkenlere ait tanımlayıcı istatistikler incelendiğinde mizah tarzları için en yüksek ortalamanın katılımcı mizah tarzı alt boyutuna ait olduğu, en düşük ortalamanın ise saldırgan mizah tarzında olduğu tespit edilmiştir. Antrenör sporcu ilişki kalitesi ölçeğinin alt boyutlarına bakıldığında, en yüksek ortalama yakınlık alt boyutundayken, en düşük ortalamanın ise tamamlayıcılık alt boyutunda olduğu görülmektedir. Takım sargınlığı alt boyutlarında ise en yüksek ortalama, görev alt boyutunda iken, sosyal sargınlık alt boyutunun ortalamasının daha düşük olduğu görülmektedir. 
Tablo 1.

Çalışmada Ele Alınan Değişkenlere Ait Betimsel İstatistikler

\begin{tabular}{lccccc}
\hline Değişkenler & $\mathrm{n}$ & En Düşük & En Yüksek & $\overline{\mathbf{x}}$ & Ss \\
\hline Katılımcı Mizah & 352 & 1,63 & 7,00 & 5,21 & 1,03 \\
Kendini Geliştirici Mizah & 352 & 1,50 & 7,00 & 4,60 & 0,97 \\
Saldırgan Mizah & 352 & 1,00 & 6,00 & 2,75 & 0,91 \\
Kendini Yıkıcı Mizah & 352 & 1,00 & 6,25 & 3,15 & 0,92 \\
Optimal Performans Duygu Durum & 352 & 1,89 & 5,00 & 3,84 & 0,52 \\
İlişki-Yakınlık & 352 & 2,50 & 7,00 & 6,52 & 0,74 \\
İlişki -Bağlılık & 352 & 1,00 & 7,00 & 6,09 & 0,52 \\
İlişki -Tamamlayıcılık & 352 & 3,00 & 7,00 & 6,07 & 0,84 \\
Zihinsel Dayanıklılık & 352 & 2,63 & 7,00 & 5,79 & 0,43 \\
Sargınlık Görev & 352 & 1,75 & 9,00 & 7,32 & 1,35 \\
Sargınlık Sosyal & 352 & 1,00 & 9,00 & 6,93 & 1,63 \\
\hline
\end{tabular}

Tablo 2.

Optimal Performans Duygu Durumun Yordanmasına İlişkin Hiyerarşik Regresyon Analizi Bulguları

\begin{tabular}{|c|c|c|c|c|c|c|c|}
\hline 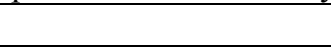 & $\beta$ & $\mathrm{t}$ & $\mathrm{p}$ & $\mathrm{R}$ & $\mathrm{R}^{2}$ & Düzeltilmiş $\mathrm{R}^{2}$ & $F_{(d f)}$ \\
\hline \multicolumn{8}{|l|}{ Model 1} \\
\hline Cinsiyet & 071 & 1,31 & , 191 & & & & \\
\hline Spor Deneyimi & ,074 & 1,37 & 171 & 0,11 & 0,01 & 0,01 & $2,16_{(2,351)}$ \\
\hline \multicolumn{8}{|l|}{ Model 2} \\
\hline Cinsiyet &, 130 & 2,49 & ,013 & \multirow{6}{*}{0,38} & \multirow{6}{*}{0,14} & \multirow{6}{*}{0,13} & \multirow{6}{*}{$9,43_{(6,351)} * *$} \\
\hline Spor Deneyimi & ,101 & 1,98 & ,048 & & & & \\
\hline Katılımcı Mizah Tarzı &, 124 & 2,15 &, 032 & & & & \\
\hline $\begin{array}{l}\text { Kendini Geliştirici } \\
\text { Mizah Tarzı }\end{array}$ & ,226 & 3,88 &, 000 & & & & \\
\hline Saldırgan Mizah Tarzı &,- 120 & $-2,15$ & ,033 & & & & \\
\hline $\begin{array}{l}\text { Kendini Yıkıcı Mizah } \\
\text { Tarzı }\end{array}$ &,- 102 & $-1,81$ & ,072 & & & & \\
\hline
\end{tabular}

Mizah tarzlarının optimal performans duygu durum düzeyini yordamasına yönelik yapılan hiyerarşik regresyon analiz sonuçlarına göre ise (Tablo 2), cinsiyet ve spor deneyimi optimal performans duygu durumunun yordayıcısı değilken, mizah tarzları optimal performans duygu durumunun anlamlı yordayıcısıdır. Modele dahil edilen tüm değişkenler (cinsiyet, spor deneyimi ve mizah tarzları) optimal performans duygu durumunun \%13'ünü açıklamaktadır. Mizah tarzlarından katılımcı $(\beta=0.12, \mathrm{p}<0,05)$ ve kendini geliştirici $(\beta=0.23, \mathrm{p}<0,01)$ mizah tarzı ile optimal performans duygu durumu arasında pozitifi bir ilişki varken; saldırgan mizah tarzı ile optimal performans duygu durumu $(\beta=-0.12, p<0,05)$ arasında negatif ilişki vardır (Tablo 2).

Tablo 3 incelendiğinde, hem modele birinci adımda dâhil edilen cinsiyet ve spor deneyiminin; hem de modele ikinci adımda dahil edilen mizah tarzlarının zihinsel dayanıklılık puanlarını yordadığı görülmektedir. Cinsiyet ve spor deneyimi ikisi birlikte, zihinsel dayanıklılık düzeyinin \%3’ünü yordarken, mizah tarzlarının zihinsel dayanıklılığı yordamaya katkısı \% 11'dir. Mizah tarzlarından katılımcı mizah tarzının zihinsel dayanıklılık ile ilişkisi pozitiftir $(\beta=0,18, \mathrm{p}<0,01)$. Öte yandan, saldırgan mizah tarzı ile zihinsel dayanıklılık arasında negatif ve anlamlı bir ilişki varken $(\beta=-0,25, \mathrm{p}<0,01)$, kendini yıkıcı, kendini geliştirici mizah tarzları ile zihinsel dayanıklılık arasında istatistiksel olarak anlamlı ilişki yoktur $(\mathrm{p}>0.05)$. 
Tablo 3.

Zihinsel Dayanıklılık Düzeyinin Yordanmasına İlişkin Hiyerarşik Regresyon Analizi Bulguları

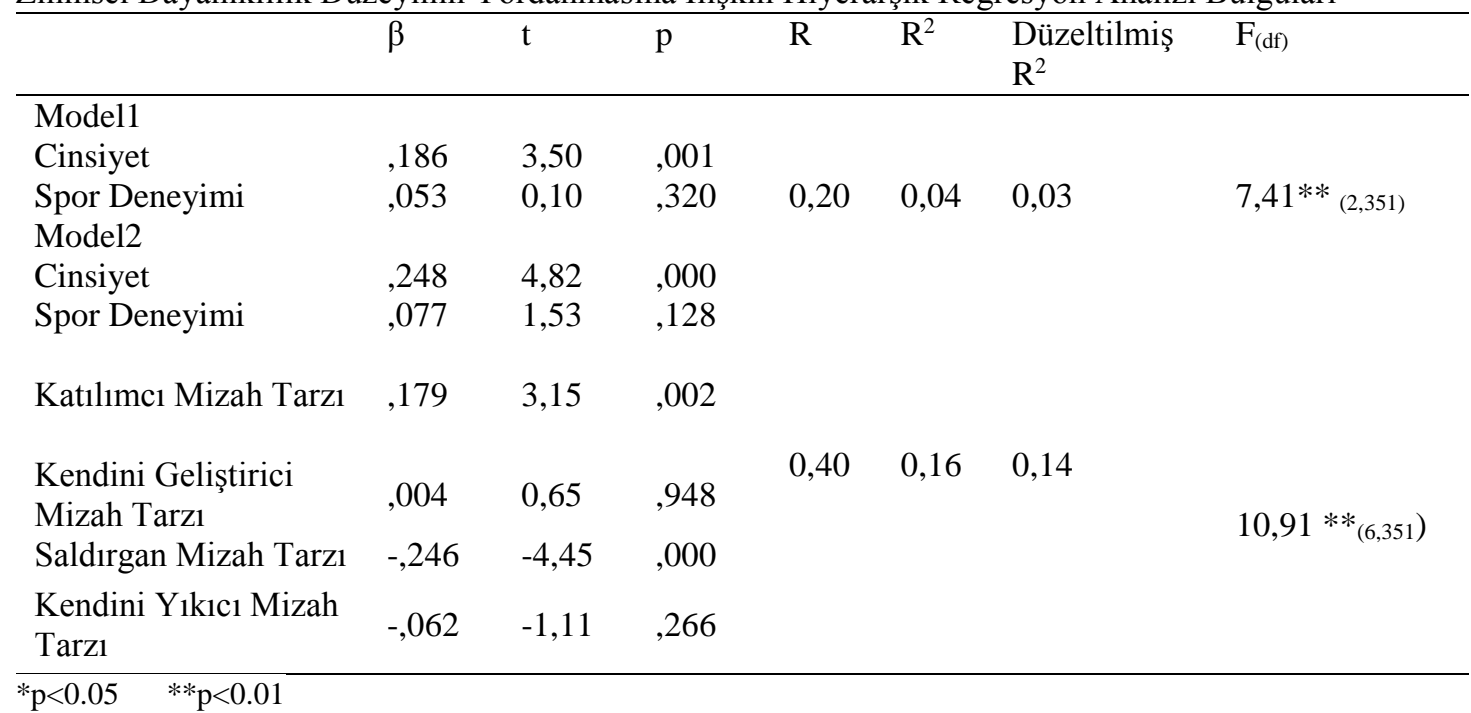

\section{Tablo 4.}

Antrenör Sporcu İlişki Kalitesinin Yordanmasına İlişkin Hiyerarşik Regresyon Analizi Bulguları

\begin{tabular}{|c|c|c|c|c|c|c|c|c|c|}
\hline \multirow[b]{2}{*}{ Model 1} & \multicolumn{3}{|c|}{ Yakınlık } & \multicolumn{3}{|c|}{ Bağlilık } & \multicolumn{3}{|c|}{ Tamamlayıcılık } \\
\hline & $\beta$ & $\mathrm{t}$ & $\mathrm{p}$ & $\beta$ & $\mathrm{t}$ & $\mathrm{p}$ & $\beta$ & $\mathrm{t}$ & $\mathrm{p}$ \\
\hline Cinsiyet & ,109 & 2,02 &, 044 & 0,77 & 1,43 &, 154 &, 131 & 2,44 &, 015 \\
\hline \multirow[t]{2}{*}{ Spor deneyimi } &, 062 & 1,15 &, 248 & ,009 & 1.17 &, 868 &, 063 & 1,17 &, 245 \\
\hline & Dzt. R & $\begin{array}{r}\mathrm{R}=0,13 \\
\mathrm{R}^{2}=0,0 \\
=0,01 ; \mathrm{I} \\
3,20 *\end{array}$ & $351)=$ & Dzt. R & $\begin{array}{r}\mathrm{R}=0,0 \\
\mathrm{R}^{2}=0,0 \\
=0.00 ; \\
1,10\end{array}$ & $351)=$ & Dzt. R & $\begin{array}{r}\mathrm{R}=0,1 \\
\mathrm{R}^{2}=0,0 \\
=0,02 ; \\
\quad 4,26 *\end{array}$ & $351)=$ \\
\hline Model 2 & $\beta$ & $\mathrm{t}$ & $\mathrm{p}$ & $\beta$ & $\mathrm{t}$ & $\mathrm{p}$ & $\beta$ & $\mathrm{t}$ & $\mathrm{p}$ \\
\hline Cinsiyet & ,149 & 2,76 & ,006 & ,113 & 2,05 & ,041 &, 172 & 3,20 & ,001 \\
\hline Spor deneyimi & ,084 & 1,59 &, 112 &, 020 & 0,38 & ,705 & 083 & 1,58 &, 114 \\
\hline Katılımcı Mizah &, 117 & 1,97 & ,049 &, 127 & 2,08 &, 038 &, 117 & 1,98 & ,049 \\
\hline Kendini Geliştirici Mizah &, 015 & 0,25 & 802 & 0,53 & 0,86 & ,391 & ,009 & 0,15 & ,878 \\
\hline Saldırgan Mizah &,- 211 & $-3,65$ &, 000 &,- 076 & $-1,28$ & ,200 &,- 206 & $-3,58$ &, 000 \\
\hline \multirow[t]{3}{*}{ Kendini Yıkıcı Mizah } &,- 006 & $-0,97$ & ,923 &,- 035 & $-0,59$ &, 556 &,- 015 & $-0,25$ &, 800 \\
\hline & \multicolumn{3}{|c|}{$\mathrm{R}=0,29$} & \multicolumn{3}{|c|}{$\mathrm{R}=0,21$} & \multicolumn{3}{|c|}{$\mathrm{R}=0,30$} \\
\hline & \multicolumn{3}{|c|}{$\begin{aligned} \text { Dzt. } \mathrm{R}^{2}= & 0,07 ; \mathrm{F}(6,351)= \\
& 5,41 * *\end{aligned}$} & \multicolumn{3}{|c|}{$\begin{aligned} \text { Dzt. } \mathrm{R}^{2}= & 0,03 ; \mathrm{F}(6,351)= \\
& 2,57 *\end{aligned}$} & \multicolumn{3}{|c|}{$\begin{aligned} \text { Dzt. } \mathrm{R}^{2}= & 0,07 ; \mathrm{F}(6,351)= \\
& 5,68^{* *}\end{aligned}$} \\
\hline
\end{tabular}

$* \mathrm{p}<0.05 \quad * * \mathrm{p}<0.01$

Tablo 4'de mizah tarzlarının antrenör sporcu ilişkisi alt boyutlarını yordamasına yönelik yapılan hiyerarşik regresyon analizi sonuçları sunulmuştur. Bu sonuçlara göre, modele dahil edilen tüm değişkenler (cinsiyet, spor deneyimi ve mizah tarzları) yakınlık $\left(\mathrm{R}=0,29 \mathrm{R}^{2}=0,09\right.$; Düzeltilmiş $\mathrm{R}^{2}=0,07 ;(\mathrm{F}(6,51)=5,41, \mathrm{p}<0,01)$ ve tamamlayıc1lık alt boyutunun $\left(\mathrm{R}=0,30 \mathrm{R}^{2}=0,09 ;\right.$ Düzeltilmiş $\mathrm{R}^{2}=0,07 ;(\mathrm{F}(6,351)=5,68, \mathrm{p}<0,01) \%$ 7'sini, bağlılık alt boyutunun ise \%3'ünü ( $\mathrm{R}=0,21$; 
$\mathrm{R}^{2}=0,04$; Düzeltilmiş $\mathrm{R}^{2}=0,03 ;(\mathrm{F}(6,51)=2,57, \mathrm{p}<0,05)$ açıklamaktadır. Analiz sonuçlarına göre, katılımcı mizah tarzı ile yakınlık $(\beta=0,12, \mathrm{p}<0,05)$, bağlılık $(\beta=0,13, \mathrm{p}<0,05)$, tamamlayıcılık alt boyutları arasında $(\beta=0.12, \mathrm{p}<0,05)$ pozitif anlamlı ilişki bulunmuştur. Saldırgan mizah tarzı ile ise yakınlık $(\beta=-0,21, p<0,05)$ ve tamamlayıcılık alt boyutları arasında $(\beta=-0.21, \mathrm{p}<0,01)$ negatif anlamlı ilişki vardır.

Takım sargınlığına ilişkin hiyerarşik regresyon analizi sonuçlarına bakıldığında (Tablo 5), analize dahil edilen tüm değişkenlerin (cinsiyet, spor deneyimi ve mizah tarzları) görev sargınlığı alt boyutunun \%5'ini $\left(R=0,27 ; R^{2}=0,07\right.$; Düzeltilmiş $\mathrm{R}^{2}=0,05$; $\left(\mathrm{F}_{(6,51)}=4,34, \mathrm{p}<0,01\right)$, sosyal sargınlık alt boyutunun ise \%3'ünü $\left(\mathrm{R}=0,22 ; \mathrm{R}^{2}=0,05\right.$; Düzeltilmiş $\mathrm{R}^{2}=0,03 ;\left(\mathrm{F}_{(6,51)}=2,79, \mathrm{p}<0,05\right)$ yordadı $\breve{g}_{1}$ bulunmuştur. Regresyon analizi sonucu, katılımcı mizah tarzının sosyal sargınlık alt boyutunun $(\beta=0,14, \mathrm{p}<0,05)$ pozitif yordayıcısı olduğunu, saldırgan mizah tarzının ise görev sargınlığı alt boyutunun $(\beta=-0,14, p<0,05)$ negatif yordayıcısı olduğunu göstermiştir.

\section{Tablo 5.}

Takım Sargınlığının Yordanmasına İlişkin Hiyerarşik Regresyon Analizi Bulguları

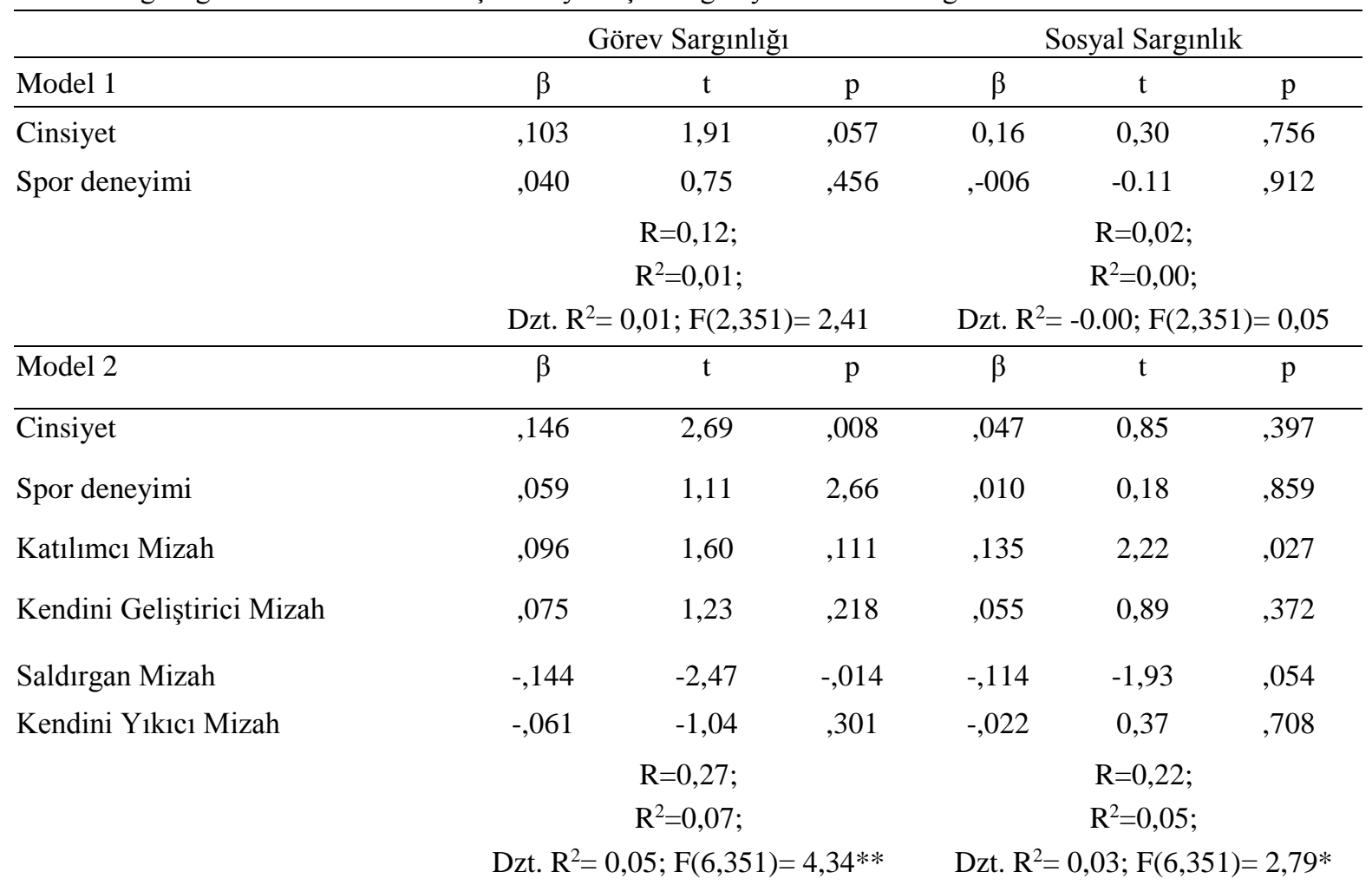

$* \mathrm{p}<0.05 \quad * * \mathrm{p}<0.01$

\section{TARTIŞMA VE SONUÇ}

Çalışmada adolesan sporcularda optimal performans duygu durumu, zihinsel dayanıklılık, antrenör sporcu ilişki kalitesi ve takım sargınlığı kavramlarının mizah tarzları ile ilişkisi incelenmiştir. Çalışma bulguları, mizah tarzlarının spora özgü kişiye ait ve kişilerarası psikolojik yapıların belirlenmesinde rol oynadığını göstermiştir.

Çalışmada ele alınan kişiye ait psikolojik yapılardan biri olan optimal performans duygu durum ile ilgili bulgulara bakıldığında, katılımcı, kendini geliştirici ve saldırgan mizah tarzlarının optimal performans duygu durumun belirlenmesinde rol oynadığı bulunmuştur. Elde edilen bulgular katılımcı ve kendini geliştirici mizah tarzının optimal performans duygu durumun yaşanmasını olumlu yönde etkilediğinin gösterirken, saldırgan mizah tarzının ise optimal performans duygu durumun deneyimlenmesini olumsuz yönde etkilediğini ortaya koymaktadır. Diğer bir deyişle, olumlu 
mizah tarzlarına sahip olmak optimal performans duygu durumu yaşama olasılığını arttııırken, kişiler arası ilişkileri zedeleyici uyumsuz ve sağlıksız bir mizah tarzı olan saldırgan mizah tarzı optimal performans duygu durumun yaşanmasını engellemektedir.

Yapılan araştırmalar, olumlu mizah tarzına sahip kişilerin, çeşitli sosyal deneyimlerden ve yaşam olaylarından daha fazla zevk ve tatmin elde ettiğini, olumsuz mizah tarzına sahip kişiler için ise bu durumun tam ters olduğunu göstermiştir (Zhao ve diğ. 2014). Dyck ve Holtzman (2013) yaşam tatmini ile olumlu mizah tarzları arasında pozitif, olumsuz mizah tarzları arasında negatif ilişki olduğunu ortaya koymuştur. Buna ek olarak, Cann ve Etzel, (2008), kişilerin sahip olduğu mizah tarzlarının iyimserlik, umut ve mutluluk gibi pozitif kişilik yapılarını etkilediğini belirtmişlerdir. Optimal performans duygu durum deneyiminin de pozitif duygu durum özellikleri ve mutluluk ile ilişkili olması (Fullagar ve Kelloway, 2009; Hunter ve Csikszentmihalyi, 2003), mutluluk ve iyimserlik gibi pozitif duygularla ilişkili olan olumlu ve olumsuz mizah tarzlarının optimal performans duygu durumunu dolaylı olarak etkilediği söylenebilir. Alan yazında yer alan bu çalışma bulgularından da görüldüğü gibi olumlu mizah tarzına sahip bireyler optimal performans duygu durum gibi olumlu yaşam çıktıları olan yüksek yaşam doyumu, mutluluk, iyimserlik gibi özelliklere sahiptirler. Olumlu mizah tarzlarına sahip kişilerin stresli olaylar karşısında mizahi bakış açılarını koruyabildikleri de bilinmektedir (Martin ve diğ. 2003). Sahip olunan mizah tarzının bu özellikleri düşünüldüğünde, olumlu mizah tarzına sahip sporcuların, takım arkadaşları ya da antrenörleriyle olan ilişkilerinde daha az sorun yaşayarak, içinde bulundukları aktiviteye tamamıla dahil olmalarını, zamanın akışına, içsel tatmine kendilerini kaptırmalarını kolaylaştıracağı, bu sebeple de optimal performans duygu durumu yaşamalarına pozitif etkisi olacağını düşünülebilir. Depresyon, zayıflık ve stres gibi yapılarla pozitif ilişkisi bulunan saldırgan mizah tarzına sahip kişilerin bu özellikleri sebebiyle aktiviteye odaklanma ve aktiviteden keyif alma, görevin farkında olma gibi kavramlara odaklanmakta zorlanacağı bu sebeple de optimal performans duygu durumu daha düşük seviyede yaşayacağı ön görülebilir. Bunun yanı sıra, Geiger ve diğ. (2019) olumlu mizah tarzlarının bilinçli farkındalığa pozitif etkisi, olumsuz mizah tarzlarının ise negatif etkisi olduğunu göstermiştir. Pineau ve diğ. (2014) yaptıkları araştırmada bilinçli farkındalığın, sporcularda optimal performans duygu durumun zorluk-beceri dengesi boyutunu olumlu yönde etkilediğini ortaya koymuştur. Benzer şekilde, Kee ve Wang (2008) bilinçli farkındalık puanı yüksek olan sporcuların, düşük bilinçli farkındalık puanına sahip sporculara göre daha yüksek optimal performans deneyimi yaşadıklarını belirtmiştir. Cathcart ve diğ . (2014) de araştırmalarında bilinçli farkındalığın optimal performansı olumlu etkilediğini bulmuşlardır. Çalışma bulgularına dolaylı olarak destek veren alan yazındaki bu bulgulardan yola çıkarak, katılımcı ve kendini geliştirici mizah tarzlarının optimal performans duygu durum deneyimine pozitif, saldırgan mizahın ise negatif etki yapacağı beklenebilir bir sonuç olduğu söylenebilir. Çalışmada ele alınan diğer bir kişiye ait psikolojik yapı olan zihinsel dayanıklılık ile ilgili bulgular, mizah tarzlarından katılımcı mizah tarzının zihinsel dayanıklılığın pozitif, saldırgan mizah tarzının ise negatif yordayıcısı olduğunu göstermektedir. Elde edilen bu bulgu olumlu mizah tarzının, sporcuların başarısızlıklar karşısında yılmadan aktiviteye devam etmesine, baskı altında mücadele ederken pozitif bakış açısını korumasına yardımcı olarak zorluk, stres ve baskı ile etkili bir şekilde baş etme becerisi olan zihinsel dayanıklılığı olumlu yönde arttırdığını göstermektedir. Olumsuz mizah tarzına sahip sporcuların zorluklarla mücadele etmekte zorlanacağı düşünülebilir. Martin ve diğ. (2003) olumsuz mizah tarzına sahip kişilerin özelliklerini ortaya koyarken, dışarıdan gelen negatif etkilere açık ve stresle başa çıkmada başarısız olduklarını göstermiştir. Zihinsel dayanıklılık için gerekli olan baskı ve zorluklara karşı net tutum sahibi olmanın gerekliliği düşünülünce olumsuz mizah tarzlarının zihinsel dayanıklılığı negatif yönde etkileyeceği beklenebilir bir sonuç olmaktadır. Olumlu ve olumsuz mizah tarzları, kişilerin mizahı kullanırken, yapıcı ve yıkıcı özelliklerini öne çıkarmaları nedeniyle sosyal çevre gelişimini etkileyeceği ve bunun da zihinsel dayanıklılığa negatif veya pozitif etkisi olacağı ön görülebilir. Alan yazın incelendiğinde 
Veselka ve diğ. (2010) 201 yetişkinin katılımıyla gerçekleştirdikleri çalışmada olumlu mizah tarzları ile zihinsel dayanıklılık arasında pozitif ve anlamlı ilişki bulunmuştur. Olumsuz mizah tarzlarının ise zihinsel dayanıklılık ile arasında negatif ve anlamlı ilişki olduğu görülmüştür. Bir diğer çalışmada Edward ve Martin (2014) mizahın pozitif psikolojideki güçlü karakter özelliği olarak yerini araştırırken 176 üniversite öğrencisi ile çalışmıştır. Araştırma sonuçları katılımcı mizah tarzının zihinsel dayanıklılık düzeyi ile pozitif ilişkili olduğunu, saldırgan mizah tarzının zihinsel dayanıklılığın devamlılık alt boyutu ile negatif ilişkiye sahip olduğunu ortaya koymuştur. Bu bulgular da çalışmamızdan elde ettiğimiz katılımcı mizahın zihinsel dayanıklılı̆̆ı pozitif yordaması, saldırgan mizahın tarzının negatif yordaması sonucu ile benzerlik göstermektedir. Buna ek olarak, saldırgan mizah tarzına sahip bireylerin stresle karşı karşıya kaldığında, kendilerine destek olacak bir sosyal ağı bulmakta zorlanacağı ve duygusal destek konusunda düşük kalacağı beklenir (Maiolino ve Kuiper, 2014). Sosyal yakınlıkla pozitif ilişkisi olan katılımcı mizah tarzının ise aynı durumda daha yüksek duygusal destek alması beklenir (Kuiper ve diğ., 2004). Katılımeı mizah ve saldırgan mizaha sahip sporcuların bu özellikleri düşünüldüğünde, stresli durumlar karşısında diğer bireylerle paylaşımı az olan saldırgan mizah tarzına sahip sporcuların zihinsel dayanıklılık düzeyinin olumsuz etkileneceği, sosyal ilişkileri güçlü olan katılımcı mizah tarzına sahip sporcuların ise zihinsel dayanıklılığının pozitif etkileneceği söylenebilir.

Çalışmada kişiye ait psikolojik yapıların yanı sıra, kişilerarası yapılar da ele alınmıştır. Antrenör sporcu ilişki kalitesi, mizah tarzları ile ilişkisi ele alınan kişilerarası yapılardan biridir. Bu ilişkiye yönelik yapılan analizler, zihinsel dayanıklılık ve optimal performans duygu duruma ilişkin elde edilen sonuçlara benzer şekilde, olumsuz mizah tarzlarından saldırgan mizah tarzının antrenör ve sporcu ilişki kalitesinin yakınlık ve tamamlayıcılık alt boyutlarının negatif yordayıcısı olduğunu; olumlu mizah tarzlarından katılımcı mizah tarzının ise yakınlık, bağlılık ve tamamlayıcılık alt boyutlarının pozitif yordayıcısı olduğunu göstermiştir. Elde edilen bu bulgu, katılımcı mizah tarzına sahip sporcuların antrenörleri ile ilişki kalitelerinin saldırgan mizah tarzına sahip sporculara göre daha iyi olduğunu ortaya koymuştur. Katılımcı mizah tarzlarının, empati kavramı ile pozitif (Hampes, 2010), yalnızlık, utangaçlık ve sosyal kaygı ile negatif ilişkisi olduğu yapılan çalışmalarla görülmüştür (Fitts ve diğ.,. 2009, Tucker ve diğ., 2013). Antrenör sporcu arasında gelişen birbirini sevme, karşılıklı güven ve saygı gibi kavramlarla ilişkili olduğu bilinen yakınlık kavramını (Davis ve diğ., 2018), ilişkinin bilişsel unsuru olan ve antrenör ile sporcuların gelecekte ilişkiyi sürdürme isteğini yordayan (Jowett ve Cockeriill, 2003, Jowett ve Ntoumanis, 2004) bağl1lık kavramını ve son olarak antrenör ile sporcunun uyumlu, hassas, motive şekilde beraber çalışmalarını açıklayan (Jowett ve Timson- Katchis, 2005) tamamlayıcılık kavramlarını düşündüğümüzde, iletişime pozitif katkı sunan, içinde bulunduğu ortama kabulü kolaylaştıran katılımcı mizah tarzının, tüm alt boyutlarda sporcuların antrenör sporcu ilişki kalitesine olumlu yönde etkileyeceği beklenebilir. Saldırgan mizah tarzına sahip bireylerin insanlarla yakınlık kurmakta zorlandığı ve sahip olduğu mizahı iletişimde olduklarına karşı saldırı aracı olarak kullandığı Martin ve diğ. (2003) tarafından ifade edilmiştir. Ayrıca saldırgan mizah tarzına sahip bireylerin, kişilerarası iletişimde uyumsuzluk gösterdiği, stresli ve depresyona daha açık, olduğu ortaya konmuştur (Kuiper ve Leite, 2010). Bu özellikler göz önüne alındığında saldırgan mizaha sahip sporcuların antrenör sporcu ilişkisinin özellikle yakınlık ve tamamlayıcılık boyutlarının olumsuz etkilenebileceği söylenebilir.

Çalışmanın mizah tarzları ile ilişkisi ele alınan bir diğer kişiler arası kavramı ise takım sargınlığıdır. Elde edilen bulgular katılımcı mizah tarzının sosyal sargınlığın pozitif yordayıcısı olduğunu; saldırgan mizah tarzının ise görev sargınlı̆̆ının negatif yordayıcısı olduğunun ortaya koymuştur. Katılımcı mizah tarzlarına sahip bireylerin takım üyeleri tarafından daha kolay kabul gördüğü ve sahip olduğu mizah tarzını kişilerarası iletişimi geliştirmek için kullandığı ve sosyal desteğin korunmasına yardımcı olduğu göz önüne alındığında takım sargınlığının bu mizah tarzından pozitif etkileneceği düşünülebilir. Saldırgan mizah tarzına sahip kişilerin ise mizahı düşmanlık ve saldırganlık, arkadaşlarıyla 
Optimal Performans Duygu Durumu, Zihinsel Dayanıklılık, Takım Sargınlığı ve Antrenör Sporcu İlişkisinin Yordayıcısı Olarak Mizah Tarzı: Adolesan Sporcular Üzerine Çalıșma

alay etmek için kullanması düşünülünce, takım sargınlığının negatif etkilenmesi beklenebilir bir sonuçtur. Alan yazın incelendiğinde Tremayne (2010) 79 üniversiteli sporcu üzerinde yaptığı araştırmada katılımcı mizah tarzının, takım sargınlığının görev ve sosyal sargınlık boyutları ile pozitif ilişkili olduğunu bulmuştur ve spor ortamında katılımcı mizah kullanımının sargınlık için olumlu etkisi olacağını belirtmiştir. Bu sonuç, araştırma sonuçlarımız ile kısmen benzerlik göstermektedir. Bir diğer çalışmada Kim ve diğ. (2018) takım içinde mizahı etkinin kullanan "takımın komedyeni”" rolündekilerin, dışa dönük kişilik özelliğine sahip olduğunu ve kişilerarası iletişime pozitif etkisi olduğunu ortaya koymuştur. Katılımcı mizah tarzının, mizahı iletişimi kolaylaştırmak için kullandığı ve bulunduğu ortamda, espri ve şakalarla yakınlık kurduğu bilinmektedir (Martin ve diğ. 2003). Bu özellikleriyle takım komedyeni rolüne bürünecek olan katılımcı mizah tarzına sahip sporcuların, arkadaşları ile daha yakın ve sosyal bir ilişki kuracağı beklenebilir bir sonuçtur. Sosyal sargınlık alt boyutu takımdaki sosyal etkileşim ve takım içi iletişim ile ilgilidir (Sezer ve Kocaekşi, 2018). Bu bağlamda da katılımcı mizah tarzının sosyal sargınlığa pozitif katkı sunacağı beklenebilir. Saldırgan mizah tarzına sahip kişilerin ise mizahı etrafındakilerle alay ederek, onları küçük görerek kullandığı bilinmektedir (Martin ve diğ. 2003). Bu tutum ortak amaçlar doğrultusunda bir araya gelen takım oyuncularının beceri, hedef ve yetenekleriyle alay edeceği düşünülen saldırgan mizah tarzına sahip sporcuların, görev sargınlığını negatif etkileyeceğini düşündürebilir.

Araştırma sonuçları göz önüne alındığında kendini yıkıcı mizah tarzının çalışmada ele alınan değişkenlerle ilişkili olmadığı görülmektedir. Kendini yıkıcı mizah tarzını kullanan kişilerin özelliklerine bakıldığında, bu tarza sahip kişilerin kendi zayıf yönleriyle dalga geçen ve mizahı sorunlarla yüzleşmekten kaçınmanın bir yolu olarak kullandıkları görülmektedir (Stieger ve diğ. 2011). Kendini yıkıcı mizah tarzına sahip olan bireyler, üzgün ya da mutsuz olduklarında bile kendi duygularını reddedip, mutluymuş, iyiymiş gibi davranabilirler. Bu özellikler düşünüldüğünde bu tarzın çalışmada ele alınan optimal performans duygu durumu ve zihinsel dayanıklılığı olumlu etkilemesi beklenebilir. Fakat, kendini yıkıcı mizah tarzı, kişisel iyi olmayı olumsuz etkiler, kendini kabulün azalmasına ve düşük benlik algısına sebep olan sağlıksız, uyumsuz bir mizah tarzıdır (Martin ve diğ. 2003). Bu özellikleri ile düşünüldüğünde ise hem çalışmada ele alınan kişiye ait hem de kişilerarası yapıları olumsuz etkilemesi beklenebilir. Yine kendini yıkıcı mizah tarzının, kişilerarası ilişkileri engelleyici olduğu (Martin ve diğ., 2003) ele alındığında, antrenör sporcu ilişki kalitesini ve takım sargınlığını olumsuz etkileme olasılığı yüksektir. Martin ve diğ. (2003) tarafından kişi içi ve kişilerarası ilişkilerde olumsuz sonuçlara yol açtığı öne sürülen kendini yıkıcı mizah tarzının, araştırma kapsamındaki psikolojik yapılarla ilişkili bulunmaması beklenmedik bir sonuç olarak görülebilir. İlerideki çalışmalarda bu durum ele alınıp detaylı bir şekilde incelenebilir.

Araştırma sonucunda kendini geliştirici mizah tarzının ise yalnızca optimal performans duygu durumunu yordadığı görülmektedir. Olumlu bir mizah tarzı olan kendini geliştirici mizah, hayatta mizahi bakış açısına sahip olma ve olaylarla eğlenme özellikleriyle tanımlanmıştır ve bir diğer olumlu mizah tarzından farklı olarak daha çok kişi içi bir yapı olarak konumlandırılmıştır (Martin ve diğ. 2003). Bu özellikleri düşünüldüğünde aktiviteye yoğun bir şekilde katılıp, odaklanıp, haz duyması ve dış etkilere karşı kapalı olması yani optimal performansa ulaşması beklenebilir bir sonuçtur. Bir diğer kişi içi yapı olan zihinsel dayanıklılığı yaşarken, katılımcı mizah tarzına kıyasla kişilerarası iletişimde daha zayıf olması ve bulunduğu ortamdakilerden sosyal destek almada daha başarısız olacağı düşünülürse, zihinsel dayanıklılığın optimal performans duygu duruma kıyasla, katılımcı mizah tarzından daha az etkilenebileceği düşünülebilir. Aynı şekilde, kendi odaklı olan bu mizah tarzına sahip sporcuların, kişiler arası ilişkilerle ilgili olan antrenör sporcu ilişki kalitesi ve takım sargınlığı üzerinde olumlu ya da olumsuz etkisi olmayacağı beklenebilir.

Sonuç olarak elde edilen bulgular, katılımcı ve saldırgan mizah tarzının optimal performans duygu durum, zihinsel dayanıklılık, antrenör sporcu ilişki kalitesi ve takım sargınlığı düzeylerinin önemli yordayıcıları olduğunu göstermiştir. 
Kendini geliştirici mizah tarzının ise sadece optimal performans duygu durumu yordadığı görülmüştür. Bu sonuç çalışmanın bazı sınırlılıkları göz önüne alınarak yordanmalıdır. Bu çalışmanın sınırlılıklarından biri; çalışma grubunun 2019-2020 sezonunda yarışmalara katılan 12-18 yaş arası takım sporcuları ile uğraşan adolesanlardan oluşmasıdır. Bireysel sporların özellikleri dikkate alındığında, elde edilen sonuçların bireysel sporlara genellenebilirliği düşüktür ve ilerideki çalışmalarda benzer yapılar bireysel sporcularda incelenebilir. Bu sınırlılıklar göz önüne alınarak ileride yapılacak çalışmalarda; farklı yaş kategorilerindeki, branşlardaki sporcuların da mizah tarzı ile optimal performans duygu durum, zihinsel dayanıklılık, antrenör sporcu ilişki kalitesi ve takım sargınlığı arasındaki ilişki ve farklılıklar değerlendirilebilir. Bununla birlikte spor psikolojisindeki motivasyon, tükenme, kaygı gibi mizah tarzlarının etkileyebileceği farklı kavramlar ile mizah tarzları arasındaki ilişki incelenebilir. Araştırmaya yönelik önerilerin yanı sıra bu çalışmanın bulgularına dayanarak; uygulayıcılar için de öneriler sunulabilir. Antrenörler ve sporculara yönelik düzenlenecek eğitim seminerlerinde, mizah tarzlarına dair farkındalık kazandırılabilir. Kişilik özelliği olarak sahip olunan mizah duygusunun, ne tarzda kullanıldığı ve kullanılan bu mizah tarzının kendileri ve çevrelerindekilere olumlu ve olumsuz ne etkileri olduğunu anlamak spor ortamında gelişme sağlayabilir. Eğer bu farkındalık arttırılabilirse, olumlu mizah kullanımını teşvik edilebilir ve sporcuların sahip oldukları mizahı kişilerarası iletişimde düşmanca kullanmasının ve spor ortamına zarar vermesinin önüne geçilebilir.

\section{Etik Kurul İzni ile İlgili Bilgiler}

Kurul Adı: Marmara Üniversitesi Sağlık Bilimleri Enstitüsü

Etik Kurulu

Tarih: 18.03.2019

Sayı No: 80 


\section{KAYNAKÇA}

1. Altıntaş, A., Çetinkalp, Z., ve Aşçı, F.H. (2012). Antrenör- sporcu ilişkisinin değerlendirilmesi: Geçerlik ve güvenirlik çalışması. Spor Bilimleri Dergisi, 23(3), 119-128.

2. Aşçı, F.H., Çağlar, E., Eklund, R.C., Altıntaş, A., ve Jackson, S. (2007). Durumluk ve sürekli optimal performans duygu durum-2 ölçekleri'nin uyarlama çalışması. Spor Bilimleri Dergisi. 18(4), 182-196.

3. Cann, A., ve Etzel, C.K. (2008). Remembering and anticipating stressors: Positive personality mediates the relationship with sense of humor. Humor: International Journal of Humor Research, 21(2), 157-178. https://doi.org/10.1515/HUMOR.2008.008

4. Cann, A., Zapata, C.L., ve Davis, B.H. (2009). Positive and negative styles of humor in communication: Evidence for the importance of considering both styles. Communication Quarterly. 57(4). 452-468. https://doi.org/10.1080/01463370903313398

5. Carron, V.A., Brawley, L.R., ve Widmeyer, W.N. (1998). The measurement of cohesiveness in sport groups. (J.L. Duda, Ed.) Advances in sport and exercise psychology measurement (s. 213-226). Morgantown: Fitness Information Technology.

6. Cathcart, S., McGregor, M., ve Groundwater, E. (2014). Mindfulness and flow in elite athletes. Journal of Clinical Sport Psychology, 8(2), 119-141. https://doi.org/10.1123/jcsp.2014-0018

7. Cowden, R.G., Meyer-Weitz, A., ve Asante, K.O. (2016). Mental toughness in competitive tennis: relationships with resilience and stress. Frontiers in Psychology. 7,320-329. https://doi.org/10.3389/fpsyg.2016.00320

8. Cox, R.H. (2012). Sport psychology. concepts and applications. (7th Ed.) (s.297-298). McGraw-Hill.

9. Csikszentmihalyi, M. (1975). Beyond boredom and anxiety. Jossey-Bass.

10. Çağlar, E., Sarı, İ., Aşçı, F.H., Jackson, S., ve Eklund, R. (2015, October 23-25). The short versions of flow scales: reliability and validity study [Conference Paper]. III. International Exercise and Sport Psychology Congress. Istanbul, Turkey.

11. Davis, L., Appleby, R., Davis, P., Wetherell, M., ve Gustafsson, H. (2018). The role of coach-athlete relationship quality in team sport athletes' psychophysiological exhaustion: implications for physical and cognitive performance. Journal of Sports Sciences. 36(17), 19851992. https://doi.org/10.1080/02640414.2018.1429176

12. Dormann, C.F., Elith, J., Bacher, S., Buchmann, C., Carl, G., Carré, G., ve diğ. (2013). Collinearity: A review of methods to deal with it and a simulation study evaluating their performance. Ecography, 36(1), 027-046. https://doi.org/10.1111/j.1600-0587.2012.07348.x

13. Dyck, K.T.H., ve Holtzmen, S. (2013). Understanding humor styles and well-being: The importance of social relationships and gender. Personality and Individual Differences. 55(1), 53-58. https://doi.org/10.1016/j.paid.2013.01.023

14. Dziegielewski, F.S., Jacinto, G.A., Laudadio, A., ve Legg-Rodriguez, L. (2003). Humor: An essential communication tool in therapy. International Journal of Mental Health. 32(3), 74-90. https://doi.org/10.1080/00207411.2003.11449592

15. Edwards, K.R., ve Martin, R.A. (2014). The conceptualization, measurement, and role of humor as a character strength in positive psychology. Europe's Journal of Psychology, 10(3), 505-519. https://doi.org/10.5964/ejop.v10i3.759

16. Erickson, J.S., ve Feldstein, W.S. (2007). Adolescent humor and its relationship to coping, defense strategies, psychological distress, and well-being. Child Psychiatry Human Development, 37(3), 255-271. https://doi.org/10.1007/s10578-006-0034-5

17. Eys, M.A., Steven, M.T., Albert, B.R., ve Carron, V.A. (2009). Perceptions of cohesion by youth sport participants. The Sport Psychologist. 23(3), 330-345. https://doi.org/10.1123/tsp.23.3.330

18. Falanga, R., De Caroli, E.M., ve Sagone, E.(2014). Humor styles, self-efficacy and prosocial tendencies in middle adolescents. Procedia - Social and Behavioral Sciences. 127, 214-218. https://doi.org/10.1016/j.sbspro.2014.03.243

19. Fidanoğlu, O. (2006). Evlilik uyumu, mizah tarzı ve kaygı düzeyi arasındaki ilişki [Yüksek Lisans Tezi]. Marmara Üniversitesi, Eğitim Bilimleri Enstitüsü.

20. Field, A. (2009). Discovering statistics using SPSS. (3rd Ed.) Sage Publications.

21. Fitts, S.D., Sebby, R.A., ve Zlokovich, M.S. (2009). Humor styles as mediators of the shyness-loneliness relationship. North American Journal of Psychology, 11(2), 257-272.

22. Ford, E.T., McCreighta, A.K., ve Richardson, K. (2014). Affective style, humor styles and happiness. Europe's Journal of Psychology, 10(3), 451-463. https://doi.org/10.5964/ejop.v10i3.766

23. Ford, E.T., Lappi, K.S., ve Holden, J. (2016). Personality, humor styles and happiness: happy people have positive humor styles. Europe's Journal of Psychology, 12(3), 320-337. doi: 10.5964/ejop.v12i3.1160

24. Fullagar, C.J., ve Kelloway, E.K. (2009). Flow at work: An experience sampling approach. Journal of Occupational and Organizational Psychology, 82(3), 595-615. https://doi.org/10.1348/096317908X357903 
25. Geiger, P.J., Herr, N.H., ve Peters, J.R. (2019). Deficits in mindfulness account for the link between borderline personality features and maladaptive humor styles. Personality and Individual Differences, 139, 19-23. https://doi.org/10.1016/j.paid.2018.10.035.

26. Goldberg, A.S. (1998). Sports slump busting: 10 steps to mental toughness and peak performance. Champaign, IL: Human Kinetics,

27. Grisaffe, C., Bloom, L.C., ve Burke, K.L. (2003). The effects of head and assistant coaches' uses of humor on collegiate soccer players' evaluation of their coaches. Journal of Sport Behavior, 26(2), 103-109.

28. Gucciardi, D.F., Gordon, S., ve Dimmock, A.J. (2009) Evaluation of a mental toughness training program for youth-aged australian footballers: a quantitative analysis. Journal of Applied Sport Psychology, 21(3), 307-323. https://doi.org/10.1080/10413200903026066.

29. Gucciardi, D.F., Hanton, S., Gordon, S., Mallett, C.J., ve Temby, P. (2016). The concept of mental toughness: tests of dimensionality, nomological network, and traitness. Journal of Personal and Individual Differences, 83(1), 26-44. https://doi.org/10.1111/jopy.12079

30. Hampes, W. (2005). Correlations between humor styles and loneliness. Psychological Reports, 96(3), 747-750. https://doi.org/10.2466\%2Fpr0.96.3.747-750.

31. Hampes, W. (2006). Humor and shyness: The relation between humor styles and shyness. Humor, 19(2), 179-187.

32. Hampes, W. (2010). The relation between humor styles and empathy. Europe's Journal of Psychology, 6(3), 34-45. https://doi.org/10.5964/ejop.v6i3.207.

33. Hill, V.Z., Besser, A., ve Stephanie, E. (2013). Laughing at the looking glass: does humor style serve as an interpersonal signal? Evolutionary Psychology Journal, 11(1), 201-226. https://doi.org/10.1177\%2F147470491301100118.

34. Høigaard, R., Haugen, T., Johansen, B.T., ve Giske, R. (2017). Team identity in youth soccer: The role of coaches' feedback patterns and use of humour. International Journal of Sports Science and Coaching, 12(6), 1-11. https://doi.org/10.1177\%2F1747954117738843.

35. Hunter, P.J., ve Csikszentmihalyi, M. (2003). The positive psychology of interested adolescents. Journal of Youth and Adolescence, 32(1), 27-35. https://doi.org/10.1023/A:1021028306392

36. Isık, U., Aceta, M., Cengiz, R., ve Kucuk, V. (2017). Investigation of the relationship between the humour styles and trait anxiety levels of students attending schools of physical education and sports. Sport in Society, 20(11), 1-9. https://doi.org/10.1080/17430437.2017.1329823.

37. Issk, U., ve Cengiz, R. (2018). The relationship between humor styles and five factor personality traits of physical education and sports students. Universal Journal of Educational Research, 6(8), 1811-1818. DOI: 10.13189/ujer.2018.060826.

38. Jackson, A.S., ve Eklund, R.C. (2004). The flow scales manual. Morgantown, WV: Fitness Information Technology.

39. Jones, G., Hanton, S., ve Connaughton, D. (2002). What is this thing called mental toughness? An investigation of elite sport performers. Journal of Applied Sport Psychology, 14(3), 205-218.

40. Jowett, S., ve Meek, A. (2000). The coach-athlete relationship in married couples: An exploratory content analysis. The Sport Psychologist, 14(2), 157-175. https://doi.org/10.1123/tsp.14.2.157

41. Jowett, S., ve Cockerill, M. (2003). Olympic medallists' perspective of the athlete-coach relationship. Psychology of Sport and Exercise, 4(4), 313-331. https://doi.org/10.1016/S1469-0292(02)00011-0

42. Jowett, S., ve Ntoumanis, N. (2004). The coach-athlete relationship questionnaire (CART-Q): Development and initial validation. Scandinavian Journal of Medicine and Science in Sports, 14(4), 245-257. https://doi.org/10.1111/j.1600-0838.2003.00338.x

43. Jowett, S., ve Timson-Katchis, M. (2005). Social networks in sport: parental influence on the coach-athlete relationship. Sport Psychologist, 19(3), 267-287. https://doi.org/10.1123/tsp.19.3.267

44. Jowett, S., ve Shanmugam, V. (2016). Relational coaching in sport: Its psychological underpinnings and practical effectiveness. In R.J Schinke, K.R. McGannon, ve B. Smith (Eds.), Routledge International Handbook of Sport Psychology (s, 471-484). Routledge.

45. Kee, H.Y., ve Wang, C.K.J. (2008). Relationships between mindfulness, flow dispositions and mental skills adoption: A cluster analytic approach. Psychology of Sport and Exercise, 9(4), 393-411. https://doi.org/10.1016/j.psychsport.2007.07.001

46. Kim, J., Gardant, D., Bosselut, G., ve Eys, M. (2018). Athlete personality characteristics and informal role occupancy in interdependent sport teams. Psychology of Sport and Exercise, 39, 193-203. https://doi.org/10.1016/j.psychsport.2018.07.011.

47. Kuiper, N.A., Grimshaw, M., Leite, C., ve Kirsh, G. (2004). Humor is not always the best medicine: Specifc components of sense of humor and psychological well-being. International Journal of Humor Research, 17(1-2), 135-168.

48. Kuiper, N.A., ve Leite, C. (2010). Personality and social sciences personality impressions associated with four distinct humor styles. Scandinavian Journal of Psychology, 51(2),115-122. https://doi.org/10.1111/j.1467-9450.2009.00734.x.

49. Liu, K.W.Y. (2012). Humor styles, self-esteem and subjective hapiness [Master Thesis]. City University of Hong Kong. Depertmant of Applied Social Studies,

50. Maiolino, N.B., ve Kuiper, N.A. (2014). Integrating humor and positive psychology approaches to psychological well-being. Europe's Journal of Psychology, 10(3), 557-570. https://doi.org/10.5964/ejop.v10i3.753. 
51. Martin, R.A., Puhlik-Doris, P., Larsen, G., Gray, J., ve Weir, K. (2003). Individual differences of uses of humor and their relation to psychological well-being: Development of the Humor Styles Questionnaire. Journal of Research in Personality, 37(1), 48-75. https://doi.org/10.1016/S0092-6566(02)00534-2.

52. Martin, R.A. (2007). The psychology of humor: An integrative approach. Elsevier Academic Press,

53. Mauriello, M., ve McConatha, T.J. (2007). Relations of humor with perceptions of stress. Psychological Reports, 101(3 pt 2), $1057-1066$. doi.org/10.2466\%2Fpr0.101.4.1057-1066

54. Nicholls, A., Polman, R., Levy, A., ve Backhouse, S. (2008). Mental toughness, optimism, pessimism, and coping among athletes. Personality and Individual Differences, 44(5), 1182-1192. https://doi.org/10.1016/j.paid.2007.11.011

55. Özgör, N., ve Aş̧̣ı, FH. (2018). 16. Spor Bilimleri Kongresi. Zihinsel Dayanıklılık Ölçeği Çocuk Formunun Türk Sporcular İçin Güvenirliği ve Geçerliği. Antalya, 1268.

56. Paez, D., Seguel, M.A., ve Sanchez, M.F. (2013). Incremental validity of alexithymia, emotional coping and humor style on happiness and psychological well-being. Journal of Hapiness Studies, 14(5), 1621-1637. https://doi.org/10.1007/s10902-012-9400-0.

57. Peterson, C., ve Seligman, M.E.P. (2004). Character strengths and virtues: A classification and handbook. Oxford University Press: American Psychological Association.

58. Pineau, T.R., Glass, C.R., Kaufman, K.A., ve Bernal, D.R. (2014). Self- and team-efficacy beliefs of rowers and their relation to mindfulness and flow. Journal of Clinical Sport Psychology, 8(2), 142-158. https://doi.org/10.1123/jcsp.2014-0019

59. Romero, J.E., ve Cruthirds, K.W. (2006). The use of humor in the workplace. Academy of Management Perspectives, 20(2), 58-69. https://doi.org/10.5465/amp.2006.20591005.

60. Romero, E., ve Pescosolido, A. (2008). Humor and group effectiveness. Humor Relations, 61(3), $395-418$. https://doi.org/10.1177\%2F0018726708088999.

61. Romero, J.E., ve Arendt, L. (2011). Variable effects of humor styles on organizational outcomes. Psychological Reports, 108(2), 649-659. https://doi.org/10.2466/07.17.20.21.PR0.108.2.649-659

62. Ronglan, L.T., ve Aggerholm, K. (2014). Humour helps: Elite sports coaching as a balancing act. Sports Coaching Review. 3(1), 33-45. https://doi.org/10.1080/21640629.2014.885776

63. Sezer. U., ve Kocaekşi, S. (2018). Genç sporcu takım sargınlı̆̆ı ölçeği’nin (GSTSÖ) psikometrik özellikleri: geçerlik ve güvenirlik çalışması. Spor Bilimleri Dergisi, 29(3), 105-114. https://doi.org/10.17644/sbd.345936

64. Stieger, S., Formann, K.A., ve Burger, C. (2011). Humor styles and their relationship to explicit and implicit self-esteem. Personality and Individual Differences, 50(5), 747-750. https://doi.org/10.1016/j.paid.2010.11.025

65. Sullivan, P. (2013). Humor styles as a predictor of satisfaction within sport teams. Humor, 26(2), 343-349.

66. Susa, M.A. (2002). Humor type, organizational climate, and outcomes: the shortest distance between an organization's environment and the bottom line is laughter [Doctoral Thesis]. Universitiy of Nebreska.

67. Szabo, A. (2003). The acute effect of humor and exercise on mood and anxiety. Journal of Leisure Research, 35(2), 152-162. https://doi.org/10.1080/00222216.2003.11949988

68. Swann, C., Keegan, R., Piggott, D., ve Crust, L. (2012). A systematic review of the experience, occurrence, and controllability of flow states in elite sport. Psychology of Sport and Exercise, 13(6), 807-819. https://doi.org/10.1016/j.psychsport.2012.05.006.

69. Tabachnick, B.G., ve Fidell, L.S. (2013). Using multivariate statistics (6th Ed.). MA: Pearson.

70. Teztel, G. (2016). Psikolojide akış kuramı ve müzik icrası bağlamında değerlendirilmesi. Konservatoryum. 3(2),1-17.

71. Thelwell, R., Weston, N., ve Greenlees, I. (2005). Defining and understanding mental toughness within soccer. Journal of Applied Sport Psychology, 17(4), 326-332. https://doi.org/10.1080/10413200500313636

72. Tremayne, H.N. (2010). The examination of humor usage and tts relationship to cohesion in male collegiate basketball [Ph.D. Thesis]. The University of North Carolina.

73. Tucker, R.P., Judah, M.R., O'Keefe, V.M., Mills, A.C., Lechner, WV., ve Davidson, C.L., ve diğ. (2013). Humor styles impact the relationship between symptoms of social anxiety and depression. Personality and Individual Differences, 55(7), 823-827. https://doi.org/10.1016/j.paid.2013.07.008

74. Veselka, L., Schermer, A.J., Martin, R.A., ve Vernon, A.P. (2010). Laughter and resiliency: a behavioral genetic study of humor styles and mental toughness. Twin Research and Human Genetics, 13(5), 442-449. https://doi.org/10.1375/twin.13.5.442

75. Yaprak, P., Güçlü, M., ve Durhan, A.T. (2018). The happiness, hardiness, and humor styles of students with a bachelor's degree in sport sciences. Behavioral Science, 8(9), 1-21. https://doi.org/10.3390/bs8090082

76. Yerlikaya, N. (2007). Lise öğrencilerinin mizah tarzları ile stresle başa çıkma tarzları arasındaki ilişsinin incelenmesi [Yüksek Lisans Tezi]. Çukurova Üniversitesi, Sosyal Bilimler Enstitüsü. 
77. Yerlikaya, E.E. (2009). Üniversite öğrencilerinin mizah tarzları ile algılanan stres, kaygı ve depresyon düzeyleri arasındaki ilişkinin incelenmesi [Doktora Tezi]. Çukurova Üniversitesi, Sosyal Bilimler Enstitüsü.

78. Yip, J.A, ve Martin R.A. (2006). Sense of humor, emotional intelligence, and social competence. Journal of Research in Personality, 40(6), 1202-1208. https://doi.org/10.1016/j.jrp.2005.08.005

79. Zhao, J., Wanga, Y., ve Kong, F. (2014). Exploring the mediation effect of social support and self-esteem on the relationship between humor style and life satisfaction in Chinese college students. Personality and Individual Differences, 64, 126-130. https://doi.org/10.1016/j.paid.2014.02.026 